\title{
Effect of Sand Percentage on the Compaction Properties and Undrained Shear Strength of Low Plasticity Clay
}

\author{
Iyad Alkroosh ${ }^{1}$, Ali Al-Robay ${ }^{1}$, Prabir Sarker ${ }^{2}$ and Saif Alzabeebee ${ }^{3}$ \\ ${ }^{1}$ Department of Civil Engineering, College of Engineering, \\ University of Al-Qadisiyah, Al-Qadisiyah, Iraq \\ ${ }^{2}$ School of Civil and Mechanical Engineering, \\ Curtin University, WA, Australia \\ ${ }^{3}$ Department of Roads and Transport Engineering, College of Engineering, \\ University of Al-Qadisiyah, Al-Qadisiyah, Iraq
}

\begin{abstract}
This paper investigates the influence of sand content on the mechanical behavior of a low plasticity clay that collected from south of Iraq (Sumer town). Samples have been prepared with sand contents of $0 \%, 10 \%, 20 \%, 30 \%$, and $40 \%$ of the clay weight. Standard Proctor and unconfined compression tests have been carried out and the optimum moisture content, maximum dry density, and undrained shear strength have been determined. The results show a gradual increasing trend of the maximum dry density with the increase of the sand content up to $30 \%$. The highest dry density reaches $1.90 \mathrm{~g} / \mathrm{cm}^{3}$ corresponding to an optimum moisture content of $12 \%$. In addition, this paper shows that the undrained shear strength is inversely proportional to the increase of the percentage of sand. The results of this work provide a useful addition to the literature regarding the behaviour or low plasticity clay-sand mixture.
\end{abstract}

Index Terms - clay sand mixture, low plasticity, optimum moisture content, undrained shear strength.

\section{INTRODUCTION}

Soil beneath building foundations are often made up of layers of clay or sand or both. The clay occasionally exists in a form described as low or high plasticity clay which is often characterized by low strength and high compressibility (Das, 2010; Cabalar et al., 2018; Ghanizadeh et al., 2020). Due to these undesirable properties, clayey soils may be considered unsuitable for supporting foundations. Building on clayey soil usually needs dredging and replacement of the clay by stronger soils. Alternately, soil improvement techniques need

ARO-The Scientific Journal of Koya University Vol. IX, No.1 (2021), Article ID: ARO.10748, 5 pages DOI:10.14500/aro.10748

Received: 14 November 2020; Accepted: 01 February 2021

Regular research paper: Published: 01 March 2021

Corresponding author's e-mail: saif.alzabeebee@qu.eud.iq Copyright (C) 2021 Iyad Alkroosh, Ali Al-Robay, Prabir Sarker, Saif Alzabeebee. This is an open-access article distributed under the Creative Commons Attribution License. to be adopted when it is difficult and costly to conduct soil replacement.

Improvement of clay properties can be achieved by compaction or with the addition of other suitable materials. Compaction is a commonly used method to improve the mechanical properties of soil supporting foundations. It is also considered as a favorite method extensively used to improve subgrade for highway embankments, earth dams, and many other engineering structures (Das, 2010). The compaction involves soil densification by removing air with application of mechanical energy. The main advantage of this process is the increase of bearing capacity and reduction of the undesirable settlements of structures (Bowles, 1996).

Dynamic compaction was found to be useful for improving the engineering properties of soft to medium clays and silts (Narendranathan and Lee, 2013). However, compaction does not always bring satisfactory results, particularly when the compacted soil is soft clay. For instance, compacted soils of quarries were often rejected because they failed to meet the minimum limit of dry density specified by the Iraqi general specifications for roads and bridges (Ministry of housing and construction, 2003). Consequently, huge earth quarries of such soil were abandoned making the contractor bear additional cost and efforts. Therefore, addition of suitable materials is considered when compaction of clays does not yield satisfactory results.

Addition of materials to improve the physical properties of clayey soils has received the attention of many researchers. Khemissa and Mahamedi (2014) proved significant increase in strength and durability of expansive over-consolidated clay when $8 \%$ of cement and $4 \%$ of lime were added to the clay. Garzón et al. (2015) concluded that the composites of phyllite clay and cement improved the engineering properties including plasticity index, maximum dry density, unconfined shear strength, and coefficient of permeability. Mixing of clay with a percentage of sand usually improves the density and strength characteristics of clay. Several researchers attempted studies investigating into the behavior of clay-sand mixtures 
and reported improved properties. Shafiee et al. (2008) investigated the undrained behavior of compacted sand-clay mixtures under monotonic load and found that the addition of sand improved the undrained shear strength. Khan et al. (2014) studied the influence of adding $20-40 \%$ of sand to natural clay of high plasticity and reported an increase in clay density and compressive strength. Kim et al. (2016) reported that for mixtures of sand and high plasticity clay, the cyclic shear strength of low-density mixtures increased and that of highdensity mixtures decreased with the increase of fines content. Deng et al. (2017) studied the effect of sand fraction on the hydro-mechanical behavior of sand-clay mixture utilizing oedometer compression test. They found that the compression response was remarkably different for the from that of common clays, where the compression behavior of the clay-sand mixture deviated from that of normal clay for the cases with vertical compression stress equal to or more than $400 \mathrm{kPa}$.

Procter test and unconfined compression strength test are commonly carried out to evaluate the quality of the improved soil. The Procter test is usually undertaken to determine the maximum dry density of compacted soil specimens. The ratio of field to laboratory densities indicates whether or not the field compaction achieved an acceptable level. The unconfined compression test is useful for estimating the undrained bearing capacity of fine-grained soil for foundations, stability of slopes, and determining the stressstrain characteristics under undrained conditions (Budhu, 2010, Benmebarek et al., 2017, Khitas et al., 2020). It is also used for design of road embankments, shallow foundations, and retaining walls (Holtz et al., 2011).

This study investigated the effect of the percentage of sand on the density of compacted clay to improve understanding of the influence of adding the sand on the mechanical response of the clay. In addition, the undrained shear strength of the compacted clay was also investigated for samples prepared at the optimum moisture content and maximum dry density for each mixing sand percent to aid understanding of the influence of the sand percentage on the undrain response of the low plasticity clay and also provide parameters that are useful for future numerical studies on the topic (Alzabeebee, 2014).

\section{METHODOLOGY}

\section{A. Site and Sample Collection}

A sampling site was selected which has the same soil properties as those of the rejected quarries. To determine a suitable site for sample collection, technical advice was sought from professional consultants who are experts in soil investigations business in the region of the middle provinces of Iraq. Sumer town, which is located at $30 \mathrm{~km}$ north east of Al-Diwaniyah city, was determined as an ideal site for sample collection. A review of the reports of past site investigations in the area found that the type of clay in demand usually exists at a depth of $1.0 \mathrm{~m}$ below the ground surface. This study adopted the American Society for Testing and Materials (ASTM) practice for soil investigation and sampling (ASTM D1452/D1452M-16, 2016). A hand auger, shovel, and manual digging accessories were used to dig the ground to reach the sampling depth. A soil of clayey nature began to appear from a depth of $0.7 \mathrm{~m}$. Initial evaluation was made to the excavated soil in the field by visual inspection and a simple field test. The soil showed sticky behavior when water was added to it and thus it was concluded that the soil is clay (Budhu, 2011). The excavated soil sample was grey in color, had a homogeneous structure, and could be easily molded by fingers. The samples were transported to the Soil Mechanics Laboratory of College of Engineering, University of Al-Qadisiyah as per standard practice for preserving and transporting soil samples (ASTM D4220/D4220M-14, 2014).

\section{B. Laboratory Work}

\section{Soil sample classification}

After the initial evaluation of the extracted sample by field test, it was evaluated further in the laboratory to ensure that the sample was clay of low plasticity. The plasticity test was carried out to determine the type of soil sample. In this test, a relationship between liquid limit and plasticity index was defined. The liquid limit and plastic limit tests were performed as per the ASTM D4318-17e1 (2017) and the unified soil classification system (USCS) was adopted to classify the soil sample (ASTM D2487-17, 2017).

\section{Removing coarse particles from the sample}

Although the collected soil sample is evaluated as clayey soil, a percentage of coarse particles were expected to exist in the sample. To obtain a purely fine- grained soil, the sample was sieved and then washed on the sieve \# 200. The passing solution was collected in a bowl and then placed in an oven with a temperature of $100^{\circ} \mathrm{C}$ for $24 \mathrm{~h}$ to remove the water. It was found that the percentage of the soil passing sieve \# 200 is more than $95 \%$.

\section{Preparing sand fraction}

The sand used in this study was available locally. It was brought from Al-Najaf Province which usually supplies sand as a construction material to most regions in Iraq. Based on the ASTM D2487-17 (2017), USCS defines sand as a portion of soil particles that pass sieve \#4 $(4.75 \mathrm{~mm})$ and retained on sieve \# $200(75 \mu \mathrm{m})$. Usually, sand contains a percentage of coarse particles of size larger than $4.75 \mathrm{~mm}$ and fine particles of size smaller than $0.075 \mathrm{~mm}$. To collect the sand grains only, an amount of soil was sieved as per the standard test method for sieve analysis of soils (ASTM D6913/D6913M-17, 2017). The particles passing through sieve \# 4 and retaining on sieve \# 200 were used in the subsequent tests.

\section{Compaction test}

The soil sample was compacted using standard Proctor's compaction tests in accordance with the ASTM D698-12e2 (2012), Method A to determine its maximum dry density and optimum moisture content. The test was carried out on the sample that contains zero percentage of sand and then on samples with $10 \%-40 \%$ of sand. The sand fraction was added as a percentage by weight varying in $10 \%$ increment. Before the test, measurements of the mold dimensions and 
its weight with the baseplate were recorded. The soil sample was prepared by adding an amount of water to the dry sample and then mixing it thoroughly to get a consistent distribution of the moisture. The sample was then compacted in Proctor's mold of $100 \mathrm{~mm}$ diameter and $117 \mathrm{~mm}$ height. The sample was placed in the mold in three layers and each layer was knocked by 25 blows distributed evenly on its surface using a standard rammer which weighs $2.5 \mathrm{~kg}$ and falls off from a height of $300 \mathrm{~mm}$. Then, the mold and the compacted soil with the base plate were weighed. A sample was taken from the core of the compacted specimen for determination of the moisture content in accordance with the ASTM standard (ASTM D2216-19, 2019). This process was continued until the weight of the compacted soil began to drop.

\section{Unconfined compression test}

This test is usually used to determine the undrained shear strength of the soil. It was also used by previous studies to investigate the shear strength of the soil (for example, Javdanian, 2017; Toufigh and Rahmannejad, 2018; Manimaran et al., 2019). Therefore, this test is used in this study to determine the influence of adding the sand on the undrained shear strength of the clayey soil. The test was conducted, according to the ASTM D2166/D216 6M- 16 (2016). The samples used in the test were extracted from the compacted soil specimen in Proctor's mold at the optimum moisture content. A steel tube of dimensions $35 \mathrm{~mm}$ in diameter and $76 \mathrm{~mm}$ in height, which is specified for the test sample, was pushed into the compacted soil sample, and pulled off with unconfined compression test sample. The sample was then extracted from the tube using the sample extruder and placed in the test frame based on the standard test method (ASTM D2166/D2166M-16, 2016). After that, a vertical stress was applied on the sample and the produced settlement was measured. The peak stress was considered as the undrained shear strength of the soil.

\section{Results AND Discussion}

As the percentage of the soil passing sieve \# 200 was found to be more than $95 \%$, this means that the classification of the soil is based on the liquid and plastic limits using the USCS (ASTM D2487-17, 2017). The plasticity test results showed that the liquid limit and plastic limit of the soil were $39 \%$ and $22 \%$, respectively. Using the plasticity chart of the USCS, the soil was classified as CL as shown in Fig. 1. This means that the soil was clay of low plasticity.

\section{A. Variation of the OMC and Maximum Dry Density with the Sand Content}

The results of the Proctor's test for the clay-sand samples which contained different fractions of sand are presented in Fig. 2. It is clear from Fig. 2 that the clay with no added sand and the clay-sand mixture soils show the similar trend for the dry density-moisture content relationship, where increasing the moisture content increases the dry density up to a certain moisture content (OMC). Beyond this optimum moisture content, the dry density declined.
To provide better insight into the effect of the sand percentage on the maximum dry density and the optimum moisture content are obtained from Fig. 2 for each case and are presented in Table I and Fig. 3. It is evident from Fig. 3 that the range of the OMC variations was between $11 \%$ and $20 \%$, where largest OMC was obtained in the sample of pure clay $(20 \%)$ and this OMC declines as the sand percentage increases. This is because the clay particles have more capability to absorb water than sand particle; hence, as the sand percentage increases the capability of the soil (claysand mixture) to absorb water decreases. On the other hand, Fig. 3 also shows that the maximum dry density varied in increasing rate from $1.65 \mathrm{~g} / \mathrm{cm}^{3}$ to reach the maximum value of $1.90 \mathrm{~g} / \mathrm{cm}^{3}$ when the sand faction was $30 \%$. The maximum dry density then dropped to $1.78 \mathrm{~g} / \mathrm{cm}^{3}$ when the sand fraction was increased to $40 \%$.

It is also clear from Fig. 3 that, there is a fast increase in dry density with increase of sand content between $10 \%$ and $30 \%$, beyond which the density declined rapidly. This is because when the sand was added to the samples, the coarse particles were arranged by compaction in a way that increased the volume of solids per unit of total volume. Hence, the void ratio decreased whereas dry density increased with the increase of sand fraction. This continued until the fraction of fine particles became less than that required for optimum arrangement of solid particles per unit volume. Therefore, the void ratio began to rise again, whereas dry density started to fall. The inverse variations in the optimum moisture content with increasing sand percentage is due to the decrease in the surface area of soil particles with the presence of sand. This led to reducing the amount of water required to facilitate the arrangement of soil particles by compaction to reach the maximum dry density (Holtz et al., 2011).

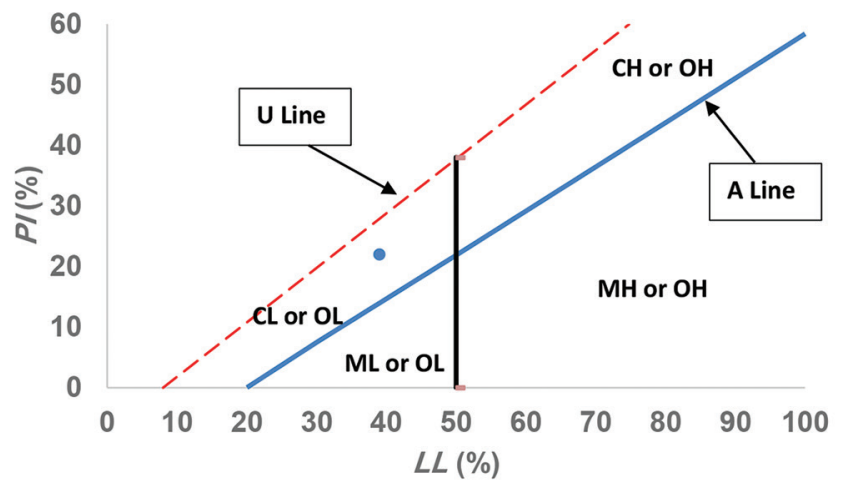

Fig. 1. Plasticity chart for classifying the soil.

TABLE I

Summary of the ObTaIned MaXimum Dry Density and Optimum Moisture CONTENT

\begin{tabular}{lcc}
\hline \hline Soil & $\begin{array}{c}\text { Maximum dry } \\
\text { density }\left(\mathrm{kg} / \mathrm{cm}^{3}\right)\end{array}$ & $\begin{array}{c}\text { Optimum moisture } \\
\text { content }(\%)\end{array}$ \\
\hline Clay with not added sand & 1.65 & 20 \\
Clay with $10 \%$ of sand & 1.80 & 15 \\
Clay with $20 \%$ of sand & 1.84 & 13 \\
Clay with $30 \%$ of sand & 1.90 & 12 \\
Clay with $40 \%$ of sand & 1.78 & 11 \\
\hline \hline
\end{tabular}



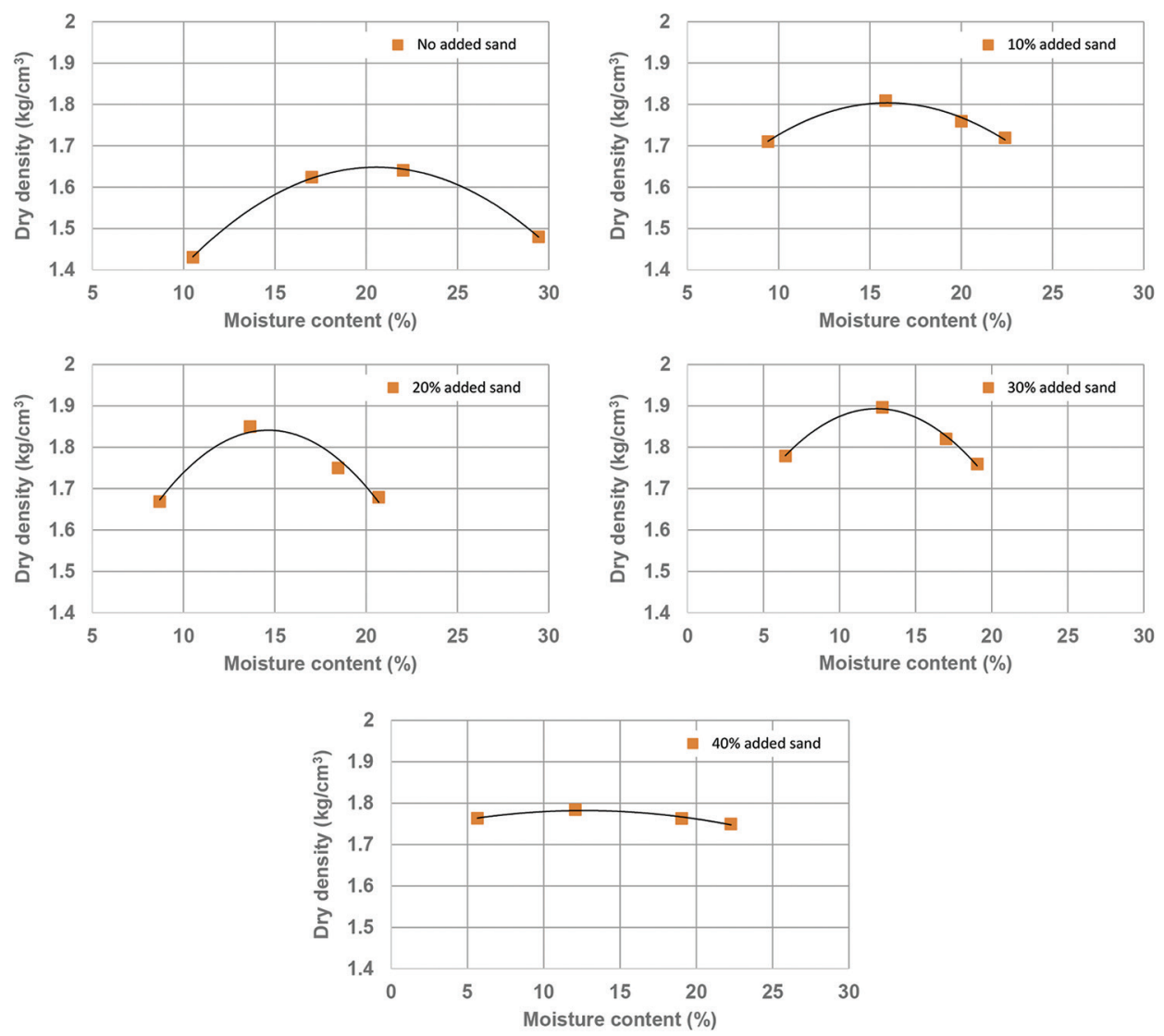

Fig. 2. Relationship of moisture content versus dry density for clay containing various sand percentages.

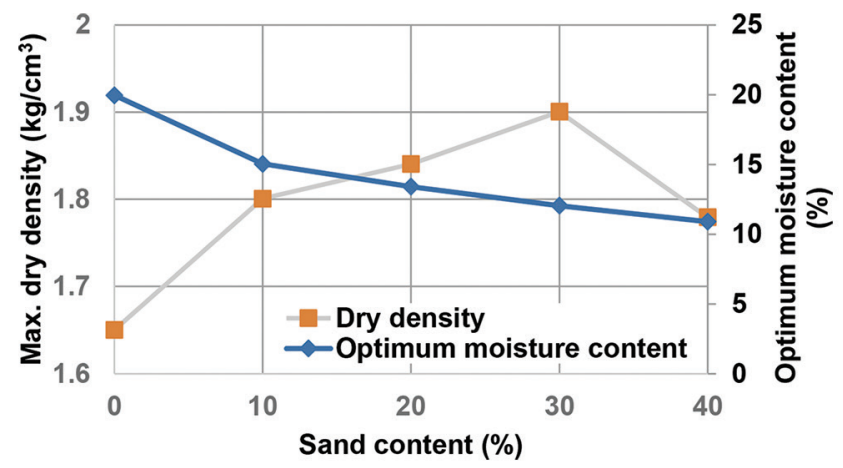

Fig. 3. Effect of sand percentage on the dry density and optimum moisture content of compacted clay.

\section{B. Variation of Undrained Shear Strength with the Sand} Content

The influence of sand fraction on the values of undrained shear strength of the compacted clay is provided in Fig. 4. It is clear from the figure that the undrained shear strength dropped from $220 \mathrm{kPa}$ for $0 \%$ sand to $111 \mathrm{kPa}$ for $40 \%$ sand. The rate of drop in the undrained shear strength continued with the increase of sand percentage. The decline in undrained shear strength with increasing sand percentage in the sample is due to the reduction in cohesion. When sand was added to the sample, the attraction between the clay particles was reduced due to the separation of clay particles by sand particles. Thus, the undrained shear strength continued to drop with

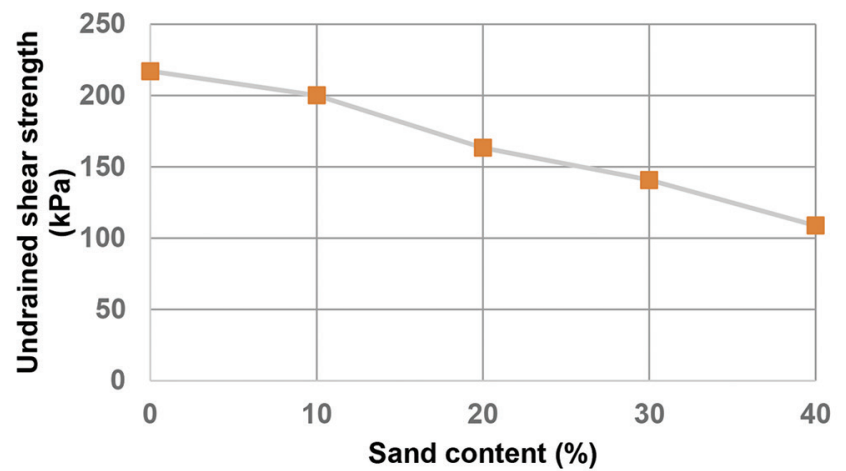

Fig. 4. Effect of sand percentage on the undrained shear strength of compacted clay.

the increasing sand fraction. Moreover, the reduction in shear strength could be attributed to the path of failure plane which passes through a weaker zone in a case of clay-sand mixes (Mullins and Panayiotopoulos, 2013). In addition, the crosssectional area of the sample may reduce when the sample contains sand particles which fell out from the sides in the test samples. As a result, stress concentration increases making the sample fail under smaller applied load (Khan et al., 2014).

\section{CONCLUSIONS}

This study investigated the characteristics of compacted clay of low plasticity mixed with sand at different percentages. 
The results have shown that dry density increased with increase of sand fraction up to $30 \%$ of the sample by weight. The maximum increase in dry density was reached when the added sand fraction was $30 \%$. The optimum moisture content decreased with the increasing percentage of added sand. The undrained shear strength varied inversely with increasing percentage of sand. A significant decrease in the undrained shear strength was observed initially with a steady decrease thereafter with the increase of sand fraction.

\section{REFERENCES}

Alzabeebee, S.I.A., 2014. Dynamic Response of Shallow Foundation on Elastic-plastic Clayey Soil Subjected to Impact Load. In: The Proceeding of the $1^{\text {st }}$ International Conference on Engineering, Al-Mustansiriya University, Iraq, pp.155-165.

ASTM D1452/D1452M-16., 2016. Standard Practice for Soil Exploration and Sampling by Auger Borings. ASTM International, West Conshohocken.

ASTM D2166/D2166M-16., 2016. Standard Test Method for Unconfined Compressive Strength of Cohesive Soil. ASTM International, West Conshohocken.

ASTM D2216-19., 2019. Standard Test Methods for Laboratory Determination of Water (Moisture) Content of Soil and Rock by Mass. ASTM International, West Conshohocken.

ASTM D2487-17., 2017. Standard Practice for Classification of Soils for Engineering Purposes (Unified Soil Classification System). ASTM International, West Conshohocken.

ASTM D4220/D4220M-14., 2014. Standard Practices for Preserving and Transporting Soil Samples. ASTM International, West Conshohocken.

ASTM D4318-17e1., 2017. Standard Test Methods for Liquid Limit, Plastic Limit, and Plasticity Index of Soils. ASTM International, West Conshohocken.

ASTM D6913/D6913M-17., 2017. Standard Test Methods for Particle-Size Distribution (Gradation) of Soils Using Sieve Analysis. ASTM International, West Conshohocken.

ASTM D698-12e2., 2012. Standard Test Methods for Laboratory Compaction Characteristics of Soil Using Standard Effort (12 $400 \mathrm{ft}-\mathrm{lbf} / \mathrm{ft} 3600 \mathrm{kN}-\mathrm{m} / \mathrm{m} 3$ ). ASTM International, West Conshohocken.

Benmebarek, S., Saifi, I. and Benmebarek, N., 2017. Depth factors for undrained bearing capacity of circular footing by numerical approach. Journal of Rock Mechanics and Geotechnical Engineering, 9, pp.761-766.

Bowles, J.E., 1996. Foundation Analysis and Design. $5^{\text {th }}$ ed. McGraw-Hill, New York.

Budhu, M., 2011. Soil Mechanics and Foundations. John Wiley and Sons, Hoboken.

Cabalar, A.F., Awraheem, M.H. and Khalaf, M.M., 2018. Geotechnical properties of a low-plasticity clay with biopolymer. Journal of Materials in Civil
Engineering, 30(8), p.04018170.

Das, B.M., 2010. Principles of Geotechnical Engineering. $7^{\text {th }}$ ed. Cengage Learning, Stamford.

Deng, Y., Wu, Z.Y., Cui S. and Wang, Q., 2017. Sand fraction effect on hydromechanical behavior of sand-clay mixture. Applied Clay Science, 135, pp.355-361.

Garzón, E., Cano, M., O’Kelly, B.C. and Sánchez-Soto, P.J., 2015. Phyllite clay-cement composites having improved engineering properties and material applications. Applied Clay Science, 114, pp.229-233.

Ghanizadeh, A.R., Yarmahmoudi, A. and Abbaslou, H., 2020. Mechanical properties of low plasticity clay soil stabilized with iron ore mine tailing and Portland cement. Journal of Mining and Environment, 11(3), pp.837-853.

Holtz, R.D., Kovacs, W.D. and Sheahan, T.C., 2011. An Introduction to Geotechnical Engineering. Prentice Hall, New Jersey.

Javdanian, H., 2017. The effect of geopolymerization on the unconfined compressive strength of stabilized fine-grained soils. International Journal of Engineering-Transactions B: Applications, 30, pp.1673-1680.

Khan, F.S., Raghunandan, M.E. and Clark, R., 2014. Compressive strength of clay-sand mixes. Advances in Material Science and Engineering, 2014, p.921815.

Khemissa, M. and Mahamedi, A., 2014. Cement and lime mixture stabilization of an expansive overconsolidated clay. Applied Clay Science, 95, pp.104-110.

Khitas, N.E.H., Benmeddour, D., Mellas, M. and Mabrouki, A., 2020. The undrained bearing capacity of strip footings under eccentric loading: effect of soil-footing interface tensile strength. International Journal of Geotechnical Engineering, 4(2), pp.169-175.

Kim, U., Kim, D. and Zhuang, L., 2016. Influence of fines content on the undrained cyclic shear strength of sand-clay mixtures. Soil Dynamics and Earthquake Engineering, 83, pp.124-134.

Manimaran, A., Seenu, S. and Ravichandran, P.T., 2019. Stimulation behaviour study on clay treated with ground granulated blast slag and groundnut shell ash. International Journal of Engineering B: Application, 32, pp.673-678.

Ministry of Housing and Construction., 2003. State commission of Road and Bridge, Revised edition of the General Specification for Road and Bridge. Department of Planning and Studies, Baghdad.

Mullins, E.C. and Panayiotopoulos, K.P., 2013. The strength of unsaturated mixtures of sand and kaolin and the concept of effective stress. Journal of Soil Science, 35, pp.459-468.

Narendranathan, N. and Lee, E.C., 2015. Dynamic compaction and dynamic consolidation of soils. Ground Improvement Case Histories, 21, pp.365-398.

Shafiee, A., Tavakoli, H.R. and Jafari, M.K., 2008. Undrained behaviour of compacted sand-clay mixtures under monotonic loading paths. Journal of Applied Sciences, 8, pp.3108-3118.

Toufigh, V. and Rahmannejad, M., 2018. Influence of curing time and water content on unconfined compressive strength of sand stabilized using epoxy resin. International Journal of Engineering B: Application, 31, pp.1187-1195. 